Економічні науки: збірник наукових праць Луцького національного технічного університету. Серія "Регіональна економіка". Випуск 18 (71). Редкол.: відп. ред. д.е.н., професор Л.Л. Ковальська. Луиьк: ІВВ Луиького НТУ, 2021. 278 с.

УДК 332.1-026.15

Фесіна Ю.Г., к.е.н., доцент

Луцький національний технічний університет

\title{
КРЕАТИВНИЙ ПОТЕНЦІАЛ РЕГІОНАЛЬНОГО РОЗВИТКУ
}

Резолюція ООН затвердила 2021 рік міжнародним роком креативної економіки задля сталого розвитку. Тому концентрація уваги на цілях формування екосистеми креативної економіки та підвищення значимості людського капіталу є важливими завданнями сьогодення. Запропоновано та обгрунтовано авторський підхід до вибору системи показників для оцінювання креативного потенціалу регіону. Здійснено оцінку індексу талантів, технологій та толерантності. Обгрунтовано науково-методичний підхід для здійснення інтегральної оцінки креативного потенціалу регіону.

Ключові слова: креативність, креативний потенціал, талант, технологія, толернатність, оцінка, регіон.

Fesina $\mathrm{Yu}$.

\section{THE CREATIVE POTENTIAL OF REGIONAL DEVELOPMENT}

The UN resolution declared 2021 the International Year of the Creative Economy for Sustainable Development. The focus on the goals of forming a creative economy ecosystem and increasing the importance of human capital are important tasks of our time. Creativity is one of the main factors of human capital development. It has not only cognitive dimension which is realized in generation of new ideas, but also depends on emotions and motivation of people, environment. In the offered approach to an estimation of creative potential of the region, the author abstracts from concrete spheres of creativity manifestation. At the same time the author tends to concentrate on the triad of classical indicators of creativity with the emphasis on the authors' substantiation of the indicators of their representation. The evaluation of the index of talents, technologies and tolerance in accordance with the proposed indicators is carried out. The scientific and methodological approach to the implementation of the integral assessment of the creative potential of the region was substantiated. According to the results of the assessment the regions were grouped into four groups - regions with a high level of creative potential, regions with an adequate level of creative potential, regions with a satisfactory level of creative potential and regions with a low level of creative potential. It is important to properly use the accumulation of creative potential and to help build it up through the formation of a creative economy ecosystem and its institutional support.

Key words: creativity, creative potential, talent, technology, tolerance, estimation, region. 
Економічні науки: збірник наукових праць Луцького національного технічного університету. Серія "Регіональна економіка". Випуск 18 (71). Редкол.: відп. ред. д.е.н., професор Л.Л. Ковальська. Луцьк: ІВВ Луцького НТУ, 2021. 278 с.

Фесина Ю.Г.

\section{КРЕАТИВНЫЙ ПОТЕНЦИАЛ РЕГИОНАЛЬНОГО РАЗВИТИЯ}

Резолюция ООН утвердила 2021 год международным годом креативной экономики для устойчивого развития. Концентрация внимания на целях формирования экосистемы креативной экономики и повышения значимости человеческого капитала являются важными задачами современности. Предложен и обоснован авторский подход к выбору системы показателей для оценки креативного потенциала региона. Осуществлена оценка индекса талантов, технологий и толерантности. Обоснован научнометодический подход к осуществлению интегральной оценки креативного потенциала региона.

Ключевые слова: креативность, креативный потенциал, талант, технология, толерантность, оценка, регион.

Постановка проблеми у загальному вигляді і її зв'язок 3 важливими науковими та практичними завданнями. Згідно 3 резолюцією ООН, 2021 р. проголошено міжнародним роком креативної економіки задля сталого розвитку. Відтак, світова спільнота сконцентрована на цілях диверсифікації економічної системи, створення екосистеми креативної економіки та підвищення значимості людського капіталу. Розвиток людського капіталу, побудований 3 акцентом на креативне мислення, сприятиме активному пошуку інноваційних рішень для протидії викликам сьогодення, швидкому прийняттю рішень для подолання проблеми розвитку нерівності. Людський капітал, поряд із економічним, соціальним та природним капіталами дозволяють забезпечити індивідуальний добробут, сприяють його зростанню. Зазначені види капіталу $\epsilon$ системоутворюючими для вимірювання добробуту та рівня прогресу в розвитку, згідно підходу ОЕСР [1]. Рамкова програма ОЕСР із регламентування системи навчання до 2030 р. розглядає креативність, як одну із ключових навичок XXI ст. [2]. Креативність базується на творчому потенціалі особистості, свободі мислення та дій, авторській генерації оригінальних ідей, що за умов наявності технологічної інфраструктури, захисту права інтелектуальної власності має стимулювати інноваційний 
Економічні науки: збірник наукових праць Луцького національного технічного університету. Серія "Регіональна економіка". Випуск 18 (71). Редкол.: відп. ред. д.е.н., професор Л.Л. Ковальська. Луиьк: ІВВ Луиького НТУ, 2021. 278 с.

процес, підтримувати розвиток підприємницького сектору, сфери креативних індустрій. За таких умов можливо забезпечити рівномірність розвитку регіонів країни.

Аналіз останніх досліджень, у яких започатковано вирішення проблеми. Останнім часом креативність розглядається в контексті невід'ємної риси креативної економіки. Вперше цей термін на позначення нового економічного напряму, який виник унаслідок трансформації індустріальної економіки, застосував у своїй публікації економічний редактор видання Bloomberg Businessweek П. Кой (Peter Coy) [3]. Згодом Дж. Говкінс (John Howkins) підтвердив думку про те, що інформація та знання стали ресурсом, а креативність - головною цінністю для іiі носія. Професор відмічав, що носії творчої риси не відіграють ніякого значення, якщо вони не створюватимуть реальний креативний продукт [4]. P. Флорида (R. Florida) вбачав у креативності можливості для економічного зростання, де тріада 3 толерантності, технологій та таланту розглядалася в якості основного рушія прогресу. При цьому дослідник відводив вирішальну роль у забезпеченні економічного розвитку виключно міським агломераціям, вважаючи їх центрами креативності та інновацій, нехтуючи роллю сільських територій [5]. Надмірна глорифікація креативного класу, урбаністичного простору для розвитку креативності, дефіцит уваги до представників некреативних індустрій, як потенційних носіїв креативності, вимагають перегляду сутності креативності та вибору іiі індикаторів. Адже, на відміну від творчих індустрій, де креативність виступає типовою рисою професії, існує ряд сфер, де примінення креативності сприяє їх розвитку та конкурентоспроможності. Безпосередньо й сам Р. Флорида виділяє не лише мистецьку чи культурну креативність, але й акцентує увагу на існуванні технологічної креативності (винахідливість) та економічної креативності (підприємливість). Всі вони тісно пов'язані, доповнюють одна одну, базуючись на процесі мислення.

На думку харківських науковиць, розвиток креативності в бізнесі має стати не лише фактором вирішення існуючих 
Економічні науки: збірник наукових праць Луцького національного технічного університету. Серія "Регіональна економіка". Випуск 18 (71). Редкол.: відп. ред. д.е.н., професор Л.Л. Ковальська. Луиьк: ІВВ Луиького НТУ, 2021. 278 с.

проблем, але й сприяти певним удосконаленням. При цьому фокус державної підтримки пропонується спрямувати виключно на креативне підприємництво, враховуючи його більшу значимість в еволюційному розвитку держави [6].

Херсонські дослідники креативної економіки, іiі основою вважають безперервний інноваційний розвиток, що базується на людському капіталі, який забезпечується інтелектуальним капіталом, креативним потенціалом і талантом [7].

Вітчизняна дослідниця креативної економіки Л. Федулова притримується думки, що регіональна політика в питанні розвитку креативної економіки має грунтуватися на розумінні іiі багатогранної сутності, що знаходить свій прояв у культурному, соціальному, економічному, технологічному, екологічному чинниках [8]. С. Давимука та Л. Федулова в спільному дослідженні креативної економіки прийшли до висновку, що для іiі належного становлення в регіоні важливо, щоб забезпечувалися певні умови: оперативна генерація нових ідей й прийняття нестандартних рішень; існування регіональної конкуренції за нові знання та ноу-хау; існування умов для розвитку особистості; оперативний обмін інформаційними потоками; розвиток комунікацій та співробітництва між населенням, господарськими одиницями й інституціями влади [9, с. 276].

Цілі статті. У контексті глобального поширення концепції креативної економіки та ії поступального становлення у вітчизняному соціально-економічному просторі, видається важливим обгрунтування необхідності оцінювання креативного потенціалу регіону для планування перспектив регіонального розвитку.

\section{Виклад основного матеріалу дослідження 3 повним обгрунтуванням отриманих наукових результатів. Креативність не може існувати сама по собі, іiі носіями виступають люди. Творчі навики людини разом із технічними навиками та досвідом, навиками вирішення проблем та спілкування, освітою, здоров'ям формують людський капітал. Учення про людський капітал в економічній теорії бере початок}


Економічні науки: збірник наукових праць Луцького національного технічного університету. Серія "Регіональна економіка". Випуск 18 (71). Редкол.: відп. ред. д.е.н., професор Л.Л. Ковальська. Луиьк: ІВВ Луиького НТУ, 2021. 278 с.

від часів А. Сміта, котрий доводив, що знання, освіта, таланти та досвід дотичні до формування багатства націй. У сьогоденні це набуло вагомого підтвердження в працях нобелівського лауреата 3 економіки - Г. Беккера, котрий економічний ріст пов'язував із синергічною взаємодією складових людського капіталу.

Спроба оцінити рівень креативності регіонів України за допомогою методики Р. Флориди, із врахуванням особливостей вітчизняної статистичної бази, була здійснена Ю. Сотніковою [10]. Дослідниця вдалася до кластерного аналізу регіонів розділивши їх на групи за рівнем розвитку креативності. При цьому враховувалися такі показники: для визначення субіндексу таланту - чисельність зайнятих у сферах креативних індустрій (професійна та наукова діяльність, сфера інформації та телекомунікацій, мистецтво, спорт, розваги й відпочинок); частка зайнятих, що мають вищу освіту; чисельність зайнятих із вищою освітою; чисельність дослідників, які працюють у регіоні; для визначення субіндексу технологій - валові витрати на виконання наукових робіт; сумарний індекс інновацій; для визначення субіндексу толерантності - відношення тривалості часу для пошуку роботи жінок у співставленні з чоловіками; кількість зареєстрованих колективних угод; чисельність мігрантів, які прибули в регіон. Оцінюючи креативний потенціал регіонів Ю. Сиваш до вище зазначених субіндексів пропонує додати субіндекс інвестиційно-інноваційного розвитку промисловості [11]. I. Вахович та О. Чуль у свій час здійснювали інтегральну оцінку розвитку креативної економіки в регіонах за конкретними сферами креативних індустрій культурна спадщина, традиційне мистецтво, творчі послуги тощо, задля визначення стратегічних орієнтирів регіонального розвитку креативної економіки [12].

Дослідниця когнітивної науки М. Боден відмічала, що первинне сприйняття креативності асоціюється 3 таємницею. Спираючись на походження терміну «креативність» формувати з нічого, приводити до буття, професорка відмічає не лише незрозумілість, але й неможливість реалізації креативної 
Економічні науки: збірник наукових праць Луцького національного технічного університету. Серія "Регіональна економіка". Випуск 18 (71). Редкол.: відп. ред. д.е.н., професор Л.Л. Ковальська. Луиьк: ІВВ Луиького НТУ, 2021. 278 с.

функції людиною. Це формує віру індивіда в те, що креативність є рідкісною та особливою силою й демотивує його творчий порив. Однак, зазначає Боден, якщо людина спиратиметься на віру в те, що креативність базується на простих навиках та фахових спроможностях, які можна розвивати наполегливою працею, то вона отримає цілком протилежний результат. Тут важливе розуміння того, що формування ментальної структури та продукування креативності вимагають тривалих затрат часу, накопичення та цільового використання енергії та максимальної концентрації на досягненні поставленої цілі в конкретній предметній області. Таким чином, креативність не $\epsilon$ рисою вродженою й монопольною для конкретної статі, раси, культури, соціального походження тощо. Це риса кожної людини, яка може проявитися за умови прикладання зусиль та реалізації можливостей [13].

У пропонованому підході до оцінювання креативного потенціалу регіону, здійснена спроба абстрагуватися від конкретних сфер прояву креативності та сконцентруватися на тріаді класичних індикаторів креативності із акцентом на авторському обгрунтуванні показників їх представлення. Для оцінювання індикатора таланту пропонується розраховувати наступні показники: питому вагу учнів, котрі склали $3 \mathrm{HO} 3$ української мови та літератури, англійської мови, математики на 180-200 балів; питому вагу населення 3 повною вищою освітою у складі робочої сили та питому вагу дослідників, котрі задіяні в науково-дослідних роботах у загальній чисельності робочої сили 3 повною вищою освітою. Таким чином, здійснена спроба відійти від пропонованого підходу до визначення талантів через їх градацію в частині так званого креативного класу. Як було зазначено вище, креативність має властивість розвиватися індивідом, тому важливо оцінювати іiі на різних стадіях людського життя. Якщо оцінювати креативність на рівні дошкільного періоду життя людини, то можна стверджувати (3 власних спостережень автора), що більшість дітей вже мають закладені іï ознаки, що проявляються в прагненні пізнання 
Економічні науки: збірник наукових праць Луцького національного технічного університету. Серія "Регіональна економіка". Випуск 18 (71). Редкол.: відп. ред. д.е.н., професор Л.Л. Ковальська. Луиьк: ІВВ Луиького НТУ, 2021. 278 с.

навколишнього світу. Креативність дитини, котра вступає в період шкільництва поступово може загасати, якщо програма підготовки не передбачає креативного підходу до вивчення шкільних навчальних предметів. Про це відмічає й Флорида, посилаючись на праці британського експерта 3 питань освіти К. Робінсона. Останній $є$ відомим критиком освітньої системи, пропагандистом індивідуального підходу до учнів та технології підтримки зацікавленості до навчання й пізнання світу. Як відмічає вітчизняна дослідниця розвитку креативності в шкільній освіті В. Павленко: «орієнтація школи на формування в учнів репродуктивної діяльності часто призводить до того, що більшість випускників, які на «відмінно» засвоїли зміст шкільної програми, не вміють використовувати отримані у школі знання під час розв'язання проблемних життєвих ситуацій» $[14$, с. 28]. Включаючи до складу індикатора таланту найвищі результати зі здачі ЗНО, ми намагалися відобразити реальну ситуацію 3 проявом креативності, що грунтується на об' єктивності (незалежне оцінювання) та особливій ситуації, яка «вмикає» необхідність проявити креативність (для школярів чітко регламентовані правила проведення ЗНО викликають деяку складну життєву обставину). Вибір на користь зазначених навчальних дисциплін обумовлений тим, що їх завдання дозволяють виявити інтелектуальні здібності, які характеризують креативну особистість: швидкість та гнучкість думки, здатність до аналізу, оригінальність. Врахування тієї обставини, що креативна економіка базується на знаннях та різноманітних формах творчого самовираження особистості, до складу індикатора було включено показник частки населення 3 вищою освітою в складі робочої сили. Це дозволило ідентифікувати ту частину продуктивних сил, яка апріорі здатна вирішувати практичні завдання 3 врахуванням креативного фактору. В свою чергу, показник частки дослідників дозволяє ідентифікувати індивідів, як правило з вищою освітою другого та третього освітнього рівня, наукового рівня (також їх представляють здобувачі третього рівня вищої освіти та здобувачі наукового рівня), які безпосередньо беруть участь в 
Економічні науки: збірник наукових праць Луцького національного технічного університету. Серія "Регіональна економіка". Випуск 18 (71). Редкол.: відп. ред. д.е.н., професор Л.Л. Ковальська. Луиьк: ІВВ Луиького НТУ, 2021. 278 с.

створенні нових знань, продуктів, процесів, систем. У загальній чисельності осіб, котрі складали ЗНО з української мови та літератури, математики й англійської мови в 2020 р., частка випускників, котрі отримали високі бали (від 180 до 200) найвища в Львівській області. Найбільша частка осіб із вищою освітою в загальній чисельності робочої сили в 2020 р. спостерігається в Рівненській області. В Харківській області найвища питома вага дослідників у складі робочої сили 3 повною вищою освітою.

Для характеристики індикатора технологій було застосовано наступні показники: забезпеченість споживачів фіксованим доступом до Інтернет у розрахунку на 100 домогосподарств регіону; забезпеченість споживачів рухомим зв'язком у розрахунку на 100 жителів регіону; частка населених пунктів регіону, охоплених технологією 4G та кількість заявок на винаходи в розрахунку на 100 дослідників регіону. Для характеристики цього індексу автор виходив 3 того, що ключовою технологією сучасності, яка дозволяє проявити креативність у всіх іiі проявах, виступає технологія Інтернет. Тому запропоновано враховувати як технічні можливості доступу до інтеренту (технологія 4G), так і забезпеченість мешканців регіону фіксованим доступом до мережі Інтернет та можливості мобільного доступу. Нині доступ до Інтернет розглядається як елемент необхідного блага, що забезпечує реалізацію інформаційно-комунікаційних функцій ососбистості. Завдяки сучасним цифровим технологіям людина отримує можливості не лише до здобуття знань, але й до демонстрації власної креативності через мультимедійні сервіси (YouTube), інформаційно-дискусійні сервіси (Livejournal), соціальні мережі (Facebook, Instagram, Tik Tok). Велику перевагу нині отримують мобільні пристрої (планшети, смартфони) в порівнянні 3 персональними комп'ютерами завдяки своїй зручності, технічним можливостям та економічним параметрам. Все це суттєво впливає не лише на покращення цифрової освіти, розвиток навичок та інклюзії, але й на доступність досліджень, інновацій, що не може не позначатись на розвитку креативності 
Економічні науки: збірник наукових праць Луцького національного технічного університету. Серія "Регіональна економіка". Випуск 18 (71). Редкол.: відп. ред. д.е.н., професор Л.Л. Ковальська. Луиьк: ІВВ Луиького НТУ, 2021. 278 с.

особистості. Широкосмугові технології доступу до мережі Інтернет, що забезпечують високу швидкість передачі та обміну даними, поширення трендів «великих даних», «інтернету речей», «хмарних обчислень» тощо стали основою для розвитку цифрової економіки, передумовою для подолання вад традиційної галузевої спеціалізації регіонів й створення нових робочих місць, активізації ролі малого та середнього підприємництва. Найвищий рівень забезпечення споживачі фіксованим доступом до Інтернет у 2020 р. спостерігається в Київській та Одеській областях - у розрахунку на 100 домогосподарств регіону 76 та 71 точки відповідно. Забезпеченість рухомим зв'язком у розрахунку на 100 мешканців регіону найвища в Київській області (188), найнижча - в Донецькій області (69). Найбільше охоплено технологією 4G населених пунктів у Полтавській області - 97,9 \% від їх загальної чисельності в регіоні, найменше - в Луганській області $(23,5$ \%). До індикатора технологій також запропоновано відносити показник кількості винаходів у розрахунку на 100 дослідників у регіоні. Даний показник характеризує рівень генерації рішень, які володіють критеріями новизни, практичності застосування та унікальності (винахідницький рівень). Як відмічає Г. Андрощук, біля $94 \%$ вітчизняних винахідників представлені інженерно-технічним персоналом та науково-педагогічними працівниками 3 вищою освітою (середній вік винахідника становить 46,4р.) [15]. В Україні в 2020 р. було подана 1361 заявка на винахід, де найбільша частка припала на Дніпропетровську область (139 заявок) та Харківську область (209 заявок). Найменше заявок подано в Чернівецькій (2), Рівненській (5), Волинській (6) та Хмельницькій (9) областях. У розрахунку на чисельність дослідників, найбільше заявок генерується в Донецькій області (16 на 100 дослідників) та Закарпатській області (13), а найменше - в Чернівецькій області (1).

3 точки зору Флориди, толерантність характеризується трьома ключовими показниками: часткою іммігрантів, індексом інтеграції (враховує розподіл етнічних та расових груп 
Економічні науки: збірник наукових праць Луцького національного технічного університету. Серія "Регіональна економіка". Випуск 18 (71). Редкол.: відп. ред. д.е.н., професор Л.Л. Ковальська. Луиьк: ІВВ Луиького НТУ, 2021. 278 с.

усередині агломерації) та індексом геїв та лесбійок (рівень привітності та сприйняття населенням сексуальних меншин). Вважається, що ці параметри толерантності впливають на бар'єри входження особистості в певний життєвий простір та можливості створення нею проєктів на основі генерування нових ідей. Слід зауважити, що для креативності якість середовища відіграє вагому роль. Чим більше середовище буде толерувати форми самовираження особистості людини, іiі свободи, тим стійкішою буде платформа для формування креативного прошарку в цьому середовищі. Створенню толерантного середовища сприяють довіра та відкритість, свобода думки та дій, знання та переконання, совість та відповідальність. Для оцінювання індикатора толерантності нами запропоновано враховувати наступні показники: гендерна толерантність (співвідношення зарплати жінок і чоловіків); сексуальна толерантність (кількість зафіксованих випадків гомота ксенофобії в розрахунку на 100 тис. мешканців регіону); правова толерантність (кількість кримінальних правопорушень на 1000 мешканців регіону); регіональна толерантність (співвідношення чисельності населення, яке прибуває в регіон та чисельності населення, яке вибуває 3 регіону). Останній показник, на погляд автора, демонструє рівень територіальної унікальності регіону. Якщо спостерігається перевищення припливу населення в регіон у співставленні з його вибуттям, то це може свідчити про сприятливість життєвого простору цього регіону. В основі такої міграційної ситуації лежить інтеграційна парадигма, яка проявляється в тріадному прояві інтеграції інтеграція в суспільство, інтеграція в суспільстві та інтеграція суспільства. Це питання досліджено в праці [16]. Загалом, як відмічають Роберта Капелло (Roberta Capello) та Пітер Найджкемп (Peter Nijkamp) [17], людському капіталу властива тенденція до міграції, що пояснює причину розвитку одних регіонів та районів у них і занепад інших. Серед регіонів країни в 2020 p. найвища чисельність прибулих у порівнянні 3 вибулими спостерігається в Київській області (вдвічі вища), Одескій області (на 22 \% більше прибуває, ніж вибуває), 
Економічні науки: збірник наукових праць Луцького національного технічного університету. Серія "Регіональна економіка". Випуск 18 (71). Редкол.: відп. ред. д.е.н., професор Л.Л. Ковальська. Луиьк: ІВВ Луиького НТУ, 2021. 278 с.

Харківській області (на 7,9 \% більше), Івано-Франківській, Львівській, Полтавській областях (приблизно на 3 \% більше) та Хмельницькій області (більше на 1,3 \%). Гендерну толерантність пропонується вимірювати через економічний критерій - співвідношення зарплат жінок і чоловіків. Найвище таке співвідношення спостерігається в Чернівецькій області $(95,5 \%)$, найнижче - в Донецькій $(62,5 \%)$. Українське суспільство поступово трансформується в систему секулярнораціональних цінностей з відносно високою часткою суспільної пам'яті про традиційні цінності та орієнтацією на цінності виживання. Це, безумовно, гальмує розвиток креативності, для якої важливе підгрунття ціннісних орієнтирів самовираження. Характеристика параметру сексуальної толерантності демонструє, що наше суспільство не готове абсолютно толерувати прояви сексуальної свободи, що на психоемоційному рівні впливає на можливості здійснення креативної діяльності відповідними особами. Більшість випадків прояву нетерпимості до чужої поведінки, манери спілкування тощо спостерігається в міських просторових середовищах (м. Київ та Київська область, м. Житомир, м. Одеса, м. Харків з прилеглими районами регіону). Коефіцієнт правової толерантності відображає прояв поваги до прав і свобод інших людей, в тому числі й в частині поваги до інституту власності. В розрахунку на 1000 жителів регіону найбільша кількість облікованих кримінальних правовопрушень у 2020 р. здійснювалася в Миколаївській $(12,8)$ та Херсонській областях $(12,4)$.

Для обчислення інтегрального індексу креативного потенціалу регіону здійснювалася побудова індексів за окремими блоками показників на основі яких будувався інтегральний індекс. Вище розглядувані показники $\epsilon$ неодноріними, а тому для співставлення їх було розділено на показники-стимулятори (іх зростання позитивно впливає на загальний рівень креативного потенціалу регіону) та показникидестимулятори (ix зниження позитивно впливає на загальний рівень креативного потенціалу регіону). Процедура стандартизації показників здійснювалася за формулою: 
Економічні науки: збірник наукових праць Луцького національного технічного університету. Серія "Регіональна економіка". Випуск 18 (71). Редкол.: відп. ред. д.е.н., професор Л.Л. Ковальська. Луцьк: ІВВ Луцького НТУ, 2021. 278 с.

$$
\begin{array}{r}
\text { - для стимуляторів: } x_{i j}=\frac{x_{i j}-x_{i \min }}{x_{i \max }-x_{i \min }} \\
\text { - для дестимуляторів: } x_{i j}=\frac{x_{i \max }-x_{i j}}{x_{i \max }-x_{i \min }}
\end{array}
$$

де $X_{i j}-$ нормоване значення показника креативної діяльності в регіоні за період дослідження;

$x_{i j}-$ значення ј-го показника для і-го об'єкта дослідження;

$x_{i \min }, x_{i \max }-$ відповідно мінімальне та максимальне значення показника по всій сукупності об'єктів дослідження.

Для показників-стимуляторів еталоном виступає максимальне значення показника, а для дестимуляторів мінімальне. Відстань до еталону розраховуємо наступним чином:

$$
\mathrm{X}=\sqrt{\sum_{i=1}^{N}\left(x_{i j}-x_{0 j}\right)^{2}}
$$

де $\mathrm{X}$ - відстань ознаки до точки еталону;

$x_{0 j}-$ точка-еталон.

Інтегральна оцінка здійснювалася 3 врахуванням того, що кожному оцінюваному об'єкту (регіону) відповідає точка 3 координатами, рівними інтегральним оцінкам згідно зазначених трьох груп індексів креативності:

$$
\mathrm{I}_{\mathrm{RIP}}=\sqrt{(\mathrm{X}-1)^{2}+(Y-1)^{2}+(Z-1)^{2}}
$$

регіону;

де $I_{\mathrm{RmF}}-$ інтегральний індекс креативного потенціалу

$\mathrm{X}, \boldsymbol{Y}, \boldsymbol{Z}$ - інтегральна оцінка індексів таланту, технологій та толерантності.

Результати інтегральної оцінки креативного потенціалу регіонів країни станом на 2020 р. та ранжування регіонів країни за іiі значенням відображено на рисунку 1. 
Економічні науки: збірник наукових праць Луцького національного технічного університету. Серія "Регіональна економіка". Випуск 18 (71). Редкол.: відп. ред. д.е.н., професор Л.Л. Ковальська. Луцьк: ІВВ Луцького НТУ, 2021. 278 с.

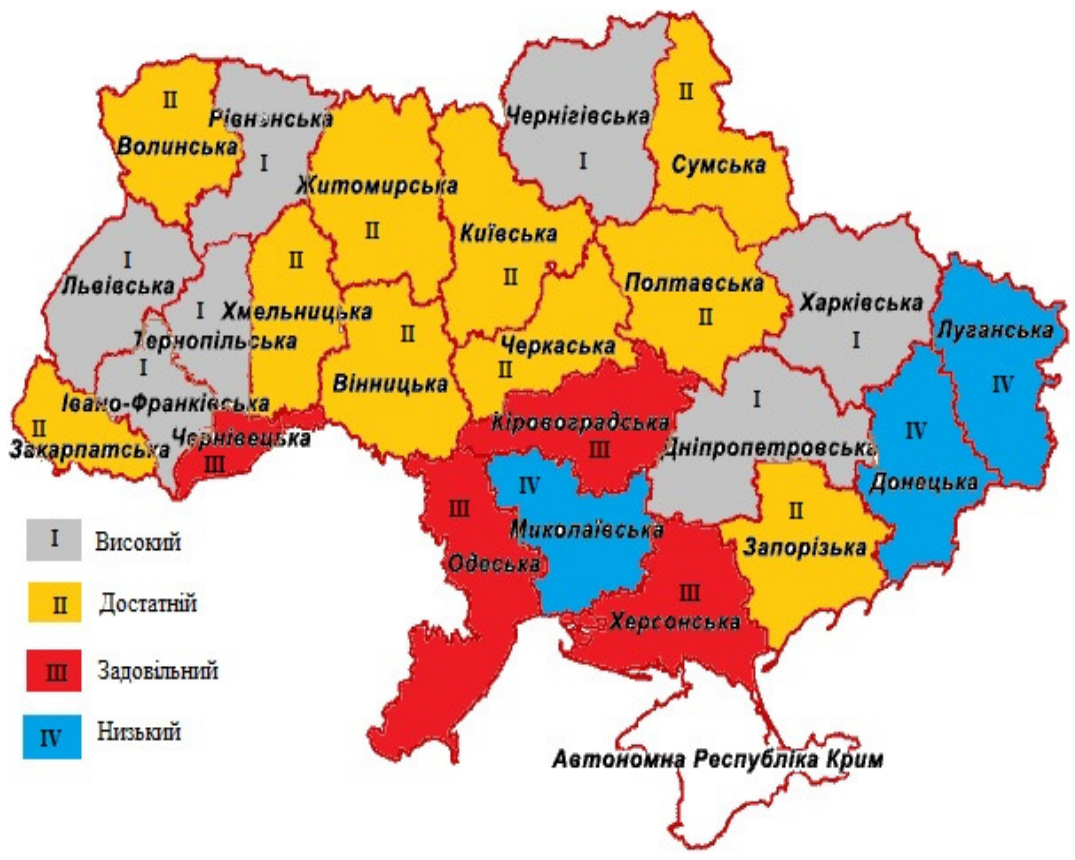

Рис. 1. Результати ранжування регіонів країни за показником інтегральної оцінки креативного потенціалу

За результатами проведеного оцінювання, регіони було згруповано на чотири групи - регіони 3 високим рівнем креативного потенціалу, регіони з достатнім рівнем креативного потенціалу, регіони із задовільним рівнем креативного потенціалу та регіони 3 низьким рівнем креативного потенціалу. За індексом талантів перші місця обіймають Львівська, Харківська та Рівненська області; за індексом технологій Київська, Івано-Франківська та Одеська області; за індексом толерантності - Івано-Франківська, Тернопільська, Чернівецька області. Інтегральна оцінка креативного потенціалу регіонів країни показала, що найвищі рівні креативного потенціалу сконцентровано в Львівській, Харківській, Івано-Франківській областях. 
Економічні науки: збірник наукових праць Луцького національного технічного університету. Серія "Регіональна економіка". Випуск 18 (71). Редкол.: відп. ред. д.е.н., професор Л.Л. Ковальська. Луиьк: ІВВ Луиького НТУ, 2021. 278 с.

До групи регіонів із високим потенціалом креативного розвитку увійшли: Львівська, Харківська, Івано-Франківська, Рівненська, Тернопільська, Чернігівська та Дніпропетровська області. Групу регіонів із достатнім рівнем креативного потенціалу склали: Сумська, Черкаська, Вінницька, Хмельницька, Житомирська, Волинська, Полтавська, Київська, Запорізька, Закарпатська області. Відмітимо, що регіон Сумщини досить близький до входження в групу регіонів із високим рівнем креативного потенціалу. До регіонів із задовільним креативним потенціалом віднесено: Кіровоградську, Чернівецьку, Одеську та Херсонську області. Найгірший креативний потенціал мають Миколаївська, Донецька та Луганська області.

Висновки. Креативність виступає одним із засадничих факторів розвитку людського капіталу. Вона має не лише когнітивний вимір, що реалізується в генеруванні нових ідей, але й залежить від емоцій та мотивації людей, оточуючого середовища. Для розвитку креативності важливий простір та різноманіття соціуму, щоб можна було комунікувати 3 предстаниками різних професій, поглядів тощо. В сільській місцевості розвивати креативність важко із-за монополії представників однієї професії, відносно однорідної діяльності. Їх тверді переконання в «силі землі» формують консервативний світогляд та несприйняття необхідності постійного пошуку себе та нових шляхів розвитку. Тому великі міські агломерації, зі своєю багатопрофільністю та розмаїттям, $є$ більш сприятливим середовищем для креативних проявів особистості. Для активізації креативного середовища традиційно аграрних регіонів та його вирівнювання 3 урбанізованим креативним простором може стати подолання проблеми цифрового розриву між містом і селом. Очевидно, що цього недостатньо й повинна бути проявлена турбота про розвиток екосистеми креативної економіки та культивування креативності в соціумі загалом. Виявлений креативний потенціал регіонів ще не є запорукою їх успішного соціально-економічного розвитку. Важливо правильно використати акумуляцію цього потенціалу та сприяти 
Економічні науки: збірник наукових праць Луцького національного технічного університету. Серія "Регіональна економіка". Випуск 18 (71). Редкол.: відп. ред. д.е.н., професор Л.Л. Ковальська. Луцьк: ІВВ Луцького НТУ, 2021. 278 с.

його нарощенню за рахунок формування екосистеми креативної економіки та здійснення ії інституційної підтримки.

\section{Список бібліографічного опису}

1. OECD Future of Education and Skills 2030. OECD Learning Compass 2030. A series of Concept Notes. Paris, OECD Publishing, 2019. 150 p. URL: https://www.oecd.org/education/2030project/contact/OECD_Learning_Compass_2030_Concept_Note_Series.pdf.

2. The Future of Education and Skills Education 2030. Paris, OECD Publishing, $2018.21 \quad$ p. URL:https://www.oecd.org/education/2030/E2030\%20Position\%20Paper\%20(05.04 .2018).pdf.

3. Peter Coy. The Creative Economy. BusinessWeek, August 28, 2000, URL: https://www.bloomberg.com/news/articles/2000-08-27/the-creative-economy.

4. John Howkins. The Creative Economy: How People Make Money From Ideas. London: Penguin Global, 2001. 288 p.

5. Флорида Р. Homo creatives. Як новий клас завойовує світ / пер. 3 англ. М. Яковлєв. Київ, 2018. 432 с.

6. Чечетова Н.Ф., Чечетова-Терашвілі Т.М. Креативне підприємництво - основа креативної економіки країни та іiі регіонів. East European Scientific Journal. 2019. № 9 (49). C. 47-52. URL:https://eesajournal.com/wp-content/uploads/47-52-Chechetova-N.F.-Chechetova-Terashvili-

T.M.-KREATIVNE-PIDPRIYeMNICTVO-\%E2\%80\%93-OSNOVAKREATIVNOYi-EKONOMIKI-KRAYiNI-TA-YiYi-REGIONIV.pdf/

7. Ушкаренко Ю.В., Чмут А.В., Синякова К.М. Креативна економіка: сутність поняття та значення для України в умовах європейської інтеграції. Економіка $i$ суспільство. 2018. Вип. 18. С. 67-72. URL: https://economyandsociety.in.ua/journals/18_ukr/10.pdf.

8. Федулова Л.І. Перспективність розвитку креативної економіки в Україні. Економічний вісник університету. 2018. Вип. 37 (1). С. 63-68.

9. Давимука С.А., Федулова Л.І. Креативний сектор економіки: досвід та напрями розбудови : монографія. Львів, 2017. 528 с.

10. Сотнікова Ю.В. Креативна економіка в Україні: реальність чи перспектива? Вісник Національного університету водного господарства та природокористування. Економічні науки. 2016. Вип. 3. С. 178-189.

11. Сиваш Ю.М. Оцінка креативного потенціалу регіонів України. Науковий вісник Ужгородського наиіонального університету. Серія: Міжнародні економічні відносини та світове господарство. 2017. Вип. 15. C. 117-120. URL: http://nbuv.gov.ua/UJRN/Nvuumevcg_2017_15\%282\%29_27.

12. Вахович I.М., Чуль О.М. Формування стратегічних оріснтирів креативного регіонального розвитку на основі кластерного аналізу. Бізнес Iнформ. 2014. № 9. C. 57-65. URL: http://nbuv.gov.ua/UJRN/binf_2014_9_10. 
Економічні науки: збірник наукових праць Луцького національного технічного університету. Серія "Регіональна економіка". Випуск 18 (71). Редкол.: відп. ред. д.е.н., професор Л.Л. Ковальська. Луцьк: ІВВ Луцького НТУ, 2021. 278 с.

13. Boden Margaret A. The Creative Mind: Myths and Mechanisms / 2nd ed. Taylor \& Francis e-Library, 2004. 344 p. URL: https://pauladaunt.com/books/The\%20Creative\%20Mind_\%20Myths\%20and\%20M echanisms.pdf.

14. Павленко В.В. Розвиток креативності молодших школярів: монографія / за ред. проф. О.С. Антонової. Житомир, 2017. 158 с.

15. Андрощук Г. Кому потрібна винахідницька діяльність в Україні? Юридична Газета. 2021. 18 жовт. (№ 19). URL: https://yurgazeta.com/publications/practice/zahist-intelektualnoyi-vlasnosti-avtorskepravo/komu-potribna-vinahidnicka-diyalnist-v-ukrayini.html.

16. Риндзак О.Т. Міграційна політика в системі інтеграційних процесів України: дис. ... д-ра екон. наук: 08.00.07 / Донецький національний університет імені Василя Стуса. Вінниця, 2020. 516 с.

17. Capello R., Nijkamp P. Handbook of Regional Growth and Development Theories. Cheltenham (UK), Northampton (MA, USA), 2009. 529 p. URL: http://herzog.economia.unam.mx/cedrus/descargas/Capello\%20$\% 20 \mathrm{HB} \% 20$ of\%20Regional\%20Growth\%20and\%20Development $\% 20$ Theories $\% 20$ $-\% 202009 . p d f$

\section{References}

1. OECD Future of Education and Skills 2030. OECD Learning Compass 2030. A series of Concept Notes. Paris, OECD Publishing, 2019. 150 p. Available at: https://www.oecd.org/education/2030project/contact/OECD_Learning_Compass_2030_Concept_Note_Series.pdf.

2. The Future of Education and Skills Education 2030. Paris, OECD Publishing, 2018. 21 p. Available at: https://www.oecd.org/education/2030/E2030\%20Position\%20Paper\%20(05.04.2018 .pdf.

3. Peter Coy. The Creative Economy. BusinessWeek, August 28, 2000. Available at: https://www.bloomberg.com/news/articles/2000-08-27/the-creativeeconomy.

4. John Howkins. The Creative Economy: How People Make Money From Ideas. London: Penguin Global, 2001. 288 p.

5. Florida R. Homo creatives. Yak novyi klas zavoiovuie svit, per. $\mathrm{z}$ anhl. M. Yakovliev. Kyiv, 2018. 432 p. [in Ukrainian].

6. Chechetova N.F., Chechetova-Terashvili T.M. Kreatyvne pidpryiemnytstvo, osnova kreatyvnoi ekonomiky krainy ta yii rehioniv. East European Scientific Journal. 2019. No 9. 47-52 pp. Available at: https://eesajournal.com/wp-content/uploads/47-52-Chechetova-N.F.-Chechetova-TerashviliT.M.-KREATIVNE-PIDPRIYeMNICTVO-\%E2\%80\%93-OSNOVAKREATIVNOYi-EKONOMIKI-KRAYiNI-TA-YiYi-REGIONIV.pdf/ [in Ukrainian].

7. Ushkarenko Yu.V., Chmut A.V., Syniakova K.M. Kreatyvna ekonomika: sutnist poniattia ta znachennia dlia Ukrainy $\mathrm{v}$ umovakh yevropeiskoi 
Економічні науки: збірник наукових праць Луцького національного технічного університету. Серія "Регіональна економіка". Випуск 18 (71). Редкол.: відп. ред. д.е.н., професор Л.Л. Ковальська. Луцьк: ІВВ Луцького НТУ, 2021. 278 с.

intehratsii. Ekonomika i suspilstvo. 2018. Vol. 18. 67-72 pp. Available at: https://economyandsociety.in.ua/journals/18 ukr/10.pdf [in Ukrainian].

8.Fedulova L.I. Perspektyvnist rozvytku kreatyvnoi ekonomiky v Ukraini. Ekonomichnyi visnyk universytetu. 2018. Vol. 37. 63-68 pp. [in Ukrainian].

9.Davymuka S.A., Fedulova L.I. Kreatyvnyi sektor ekonomiky: dosvid ta napriamy rozbudovy : monohrafiia. Lviv, 2017. 528 p. [in Ukrainian].

10. Sotnikova Yu.V. Kreatyvna ekonomika v Ukraini: realnist chy perspektyva? Visnyk Natsionalnoho universytetu vodnoho hospodarstva ta pryrodokorystuvannia. Ekonomichni nauky. 2016. Vol. 3. 178-189 pp. [in Ukrainian].

11. Syvash Yu.M. Otsinka kreatyvnoho potentsialu rehioniv Ukrainy. Naukovyi visnyk Uzhhorodskoho natsionalnoho universytetu. Seriia: Mizhnarodni ekonomichni vidnosyny ta svitove hospodarstvo. 2017. Vol. 15. 117-120 pp. Available at: http://nbuv.gov.ua/UJRN/Nvuumevcg_2017_15\%282\%29_27. [in Ukrainian].

12. Vakhovych I.M., Chul O.M. Formuvannia stratehichnykh oriientyriv kreatyvnoho rehionalnoho rozvytku na osnovi klasternoho analizu. Biznes Inform. 2014. No 9. 57-65 pp. Available at: http://nbuv.gov.ua/UJRN/binf 20149 10. [in Ukrainian].

13. Boden Margaret A. The Creative Mind: Myths and Mechanisms, 2nd ed. Taylor \& Francis e-Library, 2004. 344 p. Available at: https://pauladaunt.com/books/The\%20Creative\%20Mind_\%20Myths\%20and\%20M echanisms.pdf.

14. Pavlenko V.V. Rozvytok kreatyvnosti molodshykh shkoliariv: monohrafiia, za red. prof. O.Ie. Antonovoi. Zhytomyr, 2017. 158 p. [in Ukrainian].

15. Androshchuk H. Komu potribna vynakhidnytska diialnist v Ukraini? Yurydychna Hazeta. 2021. 18 zhovt. No 9. Available at: https://yurgazeta.com/publications/practice/zahist-intelektualnoyi-vlasnosti-avtorskepravo/komu-potribna-vinahidnicka-diyalnist-v-ukrayini.html. [in Ukrainian].

16. Ryndzak O.T. Mihratsiina polityka $\mathrm{v}$ systemi intehratsiinykh protsesiv Ukrainy: dys. ... d-ra ekon. nauk: 08.00.07, Donetskyi natsionalnyi universytet imeni Vasylia Stusa. Vinnytsia, 2020. 516 p. [in Ukrainian].

17. Capello R., Nijkamp P. Handbook of Regional Growth and Development Theories. Cheltenham, Northampton, 2009. 529 p. Available at: http://herzog.economia.unam.mx/cedrus/descargas/Capello\%20-

$\% 20 \mathrm{HB} \% 20$ of\%20Regional\%20Growth\%20and\%20Development $\% 20$ Theories $\% 20$ $-\% 202009 . p d f$

DOI: https://doi.org/10.36910/2707-6296-2021-18(71)-24 